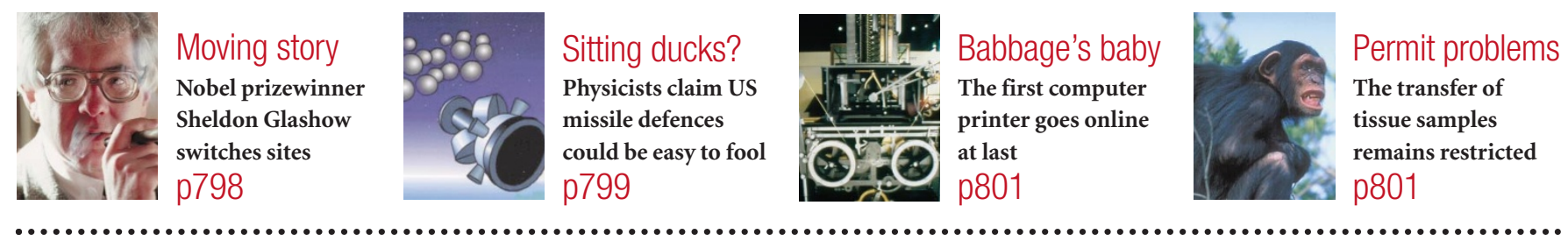

\title{
Clean-up strategy at Australian nuclear site called into question
}

Sydney

The Australian government is facing growing criticism over its remediation of the former nuclear weapons testing site in Maralinga, South Australia. Last month, the government announced that clearance of plutonium contamination from the site was "complete", and that Maralinga could now be considered "clean".

But a former technical adviser, nuclear engineer Alan Parkinson, embarrassed the government last Sunday (16 April) when he went public on national radio to attack the abandonment of plans for 'in situvitrification' (ISV) at the site. ISV electrically melts and immobilizes soil contaminants, which Parkinson believes is the best system for the site.

The government is fighting back. Jeff Harris, manager of the clean-up project, labels the allegations as "outrageous", on the grounds that "what has been done is entirely consistent with international guidelines".

But conservationists, as well as Parkinson, are now casting doubts on the government's plans and technical capacities for the disposal of civil nuclear waste.

Maralinga was the site of seven British nuclear explosions and about 700 simulated explosions between 1956 and 1963, during which $24.2 \mathrm{~kg}$ of plutonium was spread over $120 \mathrm{sq} \mathrm{km}$. The highest contamination was in 21 pits where the British shovelled debris from conventional explosions, which they had encased in plutonium to gauge safety.

A Royal Commission of inquiry in 1985 and media publicity forced Britain to acknowledge having withheld vital information on the extent of the contamination and to agree to pay nearly half of the $\mathrm{A} \$ 108$ million (US\$65 million) budgeted for the clean-up.

ISV was developed by the Battelle Corporation in the United States for treating otherwise intractable chemical contamination. Maralinga was the largest commercial application of the technique, and the first time it had been used on plutonium.

But ISV was abandoned at the site after an explosion during vitrification in the 11th pit. Although the explosion caused no injuries, the government claimed it had not been satisfactorily explained. A radiation risk to work-

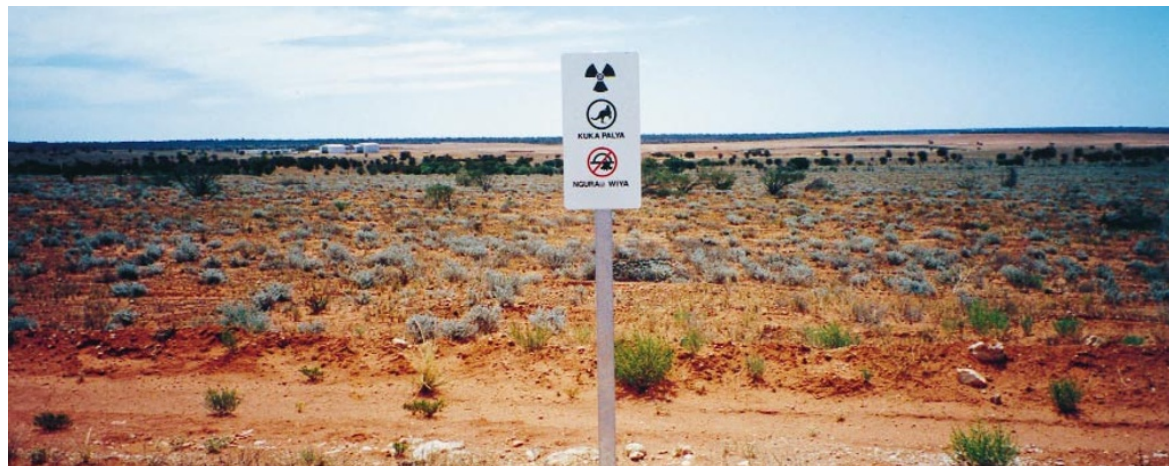

A clean sweep? Contaminated by years of nuclear testing, some land remains unsafe for habitation.

ers was cited as one reason for terminating ISV. Geosafe disputed the decision. The rest of the site was cleaned up by exhuming the plutonium from the pits and re-burying it.

On announcing completion of the project last month, Nick Minchin, the Minister for Industry, Science and Resources, said the government rested on the best scientific advice, and released a statement from the independent Australian Radiation Protection and Nuclear Safety Agency (ARPANSA) that said the burial trenches "were constructed consistent with" an Australian 1992 code of practice.

But Parkinson is supported by three members of the government's five-man technical advisory panel, which originally drafted the code. They say it was solely for near-surface burial of short-lived radioac- tive waste and "was never meant to apply to the burial of plutonium-239".

ARPANSA was formed last year by merging the Australian Radiation Laboratory and the Nuclear Safety Bureau. Maralinga is seen as its first big test, and has led critics to question the body's degree of independence from Minchin's department, which paid for its work. ARPANSA chief executive John Loy, however, does "not see any issue".

With support from ARPANSA, Minchin's department is planning a repository for low-level waste, also in the "outback" of South Australia, a requirement for final approval of a new research reactor. But critics allege the Maralinga experience has clouded the capabilities of the bodies involved in both projects.

Peter Pockley

\section{UK defence research goes private}

\section{London}

Some three-quarters of the British government's defence research agency is poised to be sold off into the private sector, under proposals issued earlier this week.

The Defence and Evaluation Research Agency (DERA), which employs more than 11,500 staff, works on projects ranging from advanced electronics to countermeasures against biological weapons. Many of its technologies have civil, as well as military applications, and the government argues that commercial status will allow DERA to compete more effectively for industrial research contracts.

An earlier plan, under which the government would have retained just a few hundred staff working on sensitive projects, was attacked by DERA's industrial collaborators and trade unions (see Nature $402,223 ; 1999)$. The new consultation document proposes retaining a larger proportion of DERA — about 3000 staff in public ownership. Peter Aldhous 